\title{
Optical and Electrical Properties of $\left(\mathrm{SnO}_{2}\right)_{\mathrm{X}}\left(\mathrm{In}_{2} \mathrm{O}_{3}\right)_{1-\mathrm{X}}$ thin Films Prepared by Pulse Laser Deposition Technique
}

\author{
Kadhem A. Aadim, Abdulmajeed E. Ibrahim², Qutaibah A. Abduljabbar," \\ ${ }^{1}$ Department of Physics, University of Baghdad / College of Sciences \\ ${ }^{2}$ Department of Physics, University of Tikrit/College of Education \\ *Corresponding author: qutaibahalrawi5378@gmail,com
}

\begin{abstract}
In this work, fundamental wavelength $(1064 \mathrm{~nm})$ Q- switched Nd:YAG laser with $800 \mathrm{~mJ}$ peak energy on $\mathrm{SnO}_{2}: \mathrm{In}_{2} \mathrm{O}_{3}$ target to produce ITO thin films. Thin films characterized by UV-visible absorbance, DC conductivity, Hall effect measurements and X-ray diffraction. It was found that the transmission increase with increasing $\mathrm{In}_{2} \mathrm{O}_{3}$ ratio from 0 to 0.5 reaching about $88 \%$ in visible range. It can be seen that the conductivity increase with increasing ratio from 0 to 0.3 then decrease at 0.5 ratio. It can be found from Hall effect measurement that the mobility $\mu_{\mathrm{H}}$ increase at 0.1 ratio then decrease with more $\operatorname{In}_{2} \mathrm{O}_{3}$ content.
\end{abstract}

\section{Keywords: ITO, XRD, DC conductivity, UV-visible}

Cite This Article: Kadhem A. Aadim, Abdulmajeed E. Ibrahim, and Qutaibah A. Abduljabbar, "Optical and Electrical Properties of $\left(\mathrm{SnO}_{2}\right)_{\mathrm{X}}\left(\mathrm{In}_{2} \mathrm{O}_{3}\right)_{1-\mathrm{x}}$ thin Films Prepared by Pulse Laser Deposition Technique." International Journal of Physics, vol. 5, no. 4 (2017): 116-120. doi: 10.12691/ijp-5-4-3.

\section{Introduction}

Conducting oxide thin films are being an important component in different optoelectronic devices such as solar cells [1], light emitting diodes [2] and photodiodes devices [3] in which they are used as transparent electrodes. The resistivity of these electrodes should be minimized as much as possible with keeping its high optical transparency particularly over the visible region of the solar spectrum. Indium Tin oxide ITO is a promising material due to its exclusive properties such as high electrical conductivity, high optical transparency for light $[4,5]$.

A transparent electrode is needed in manufacturing of solar cells on the side where light enters. Normally, transparent conductive oxides (TCO) like indium tin oxide (ITO) or zinc oxide ( $\mathrm{ZnO})$ are commonly used for such purpose [6].

We need to study the optical and electrical properties for used to reach optimum conditions for preparation ITO films. The unique properties of ITO come from its structure and composition.

One unit cell contains 16 units of $\operatorname{In}_{2} \mathrm{O}_{3}$. Therefore, for defect free $\operatorname{In}_{2} \mathrm{O}_{3}$ crystal, there are 80 atoms in one unit cell. The lattice constant is reported to be $10.118 \AA$ [7]. When tin atoms substitute for indium atoms, it forms either $\mathrm{SnO}$ or $\mathrm{SnO}_{2}$ If $\mathrm{SnO}$ is formed, tin acts as an acceptor since it accepts an electron. Otherwise, when $\mathrm{SnO}_{2}$ is formed, it acts as donor. The material retains its bixbyite structure. However, if the doping level is extremely high, the tin atoms may enter interstitially and distort the lattice structure. The high transparency in the visible wavelength range of $400-800 \mathrm{~nm}$ was explained by a low concentration of mid-gap states, typically responsible for absorption of photons with energies below the band-gap energy [8].

As the tin concentration increases, the carrier concentration increases until a saturation level is reached. An increase in the tin concentration above this saturation level causes a decrease in the free carrier concentration. ITO has metal like electrical properties because the carrier concentration is typically around $10^{20}$ to $10^{21} \mathrm{~cm}^{-3}$.

$\mathrm{X}$-ray diffraction Bragg's law was used to calculate inter-plane distance for crystals $\left(\mathrm{d}_{\mathrm{hkl}}\right)$ from the condition of X-ray diffracted interference from parallel planes [9]

$$
\mathrm{n} \lambda=2 \mathrm{~d}_{\mathrm{hkl}} \sin \theta
$$

where $\theta$ is diffraction angle and $\lambda$ is the used XRD wavelength.

The x-ray diffraction peaks broadening is used to calculate crystalline size by Scherrer equation formula [10].

$$
\mathrm{G} . \mathrm{S}=\frac{0.9 \lambda}{\text { FWHM } \cdot \cos (\theta)}
$$

Where $\lambda$ is the used $\mathrm{x}$-ray wavelength, FWHM is full width at half maximum (in radians) and $\theta$ is diffraction angle.

\section{Experimental Part}

Stannic oxide $\left(\mathrm{SnO}_{2}\right)$ purity $(99.98 \%)$ powder by FERAK, England Company and Indium (III) oxide 
$\left(\mathrm{In}_{2} \mathrm{O}_{3}\right)$, with purity $(99.9 \%)$ by Hi Media Laboratories Pvt.Ltd. (India) of these materials were mixed, with different $\mathrm{In}_{2} \mathrm{O}_{3}: \mathrm{SnO}_{2}$ ratio $(0,10,30$ and 50) \% in gate mortar to use it to make target as a disk of $1.5 \mathrm{~cm}$ diameter and $0.3 \mathrm{~cm}$ thickness using hydraulic piston type (SPECAC), under pressure of 6 tons for 10 minutes

$\mathrm{SnO}_{2}, \mathrm{In}_{2} \mathrm{O}_{3}$ and $\mathrm{SnO}_{2}: \mathrm{In}_{2} \mathrm{O}_{3}$ thin films were prepared by $\mathrm{Q}$ switched pulsed laser laser (Huafei Tongda Technology- DIAMOND-288 pattern EPLS) $\lambda=1064 \mathrm{~nm}$ with $800 \mathrm{~mJ}$ peak power inside a vacuum chamber at vacuum $\left(10^{-3}\right.$ Torr) using double stage rotary pump. Pulsed laser used to growth thin film by interaction of the pulsed laser beam with a target formed laser-induced plasma used to deposit thin films on glass substrates at low pressure. The set-up of laser deposition chamber photograph is given in Figure 1. The focused Nd:YAG SHG Q-switching laser incident beam coming through a window is making an angle of $45^{\circ}$ with the target surface. The substrate is placed parallel in front of the surface of the target.

The produced films were characterized by X-ray diffraction (XRD), Dc conductivity, Hall effect measurements and UV-visible absorption to study the effect of $\mathrm{In}_{2} \mathrm{O}_{3}: \mathrm{SnO}_{2}$ ratio on produced thin films properties.

\section{Results and Discussion}

Figure 2 displays $\mathrm{X}$ - ray diffraction for $\mathrm{In}_{2} \mathrm{O}_{3}: \mathrm{SnO}_{2}$ composite with different ratio deposited on glass substrate and annealed at $773 \mathrm{~K}$. The pure sample pattern have four peaks located at $2 \theta$ about 26.5201, 33.8462, 37.9487 and $51.7216^{\circ}$ corresponding to (110), (101), (200) and (211) direction respect to $\mathrm{SnO}_{2}$ crystals. It can be seen that these peaks vanished gradually with increasing $\mathrm{In}_{2} \mathrm{O}_{3}$ ratio with appearance of $\mathrm{In}_{2} \mathrm{O}_{3}$ peaks with high degree of crystallinety. The full width of half maximum (FWHM) for observed peaks increase with increasing ratio, i.e decreasing the crystalline size with increasing. Table 1 shows all peaks observed in XRD and a comparison with standard peaks.

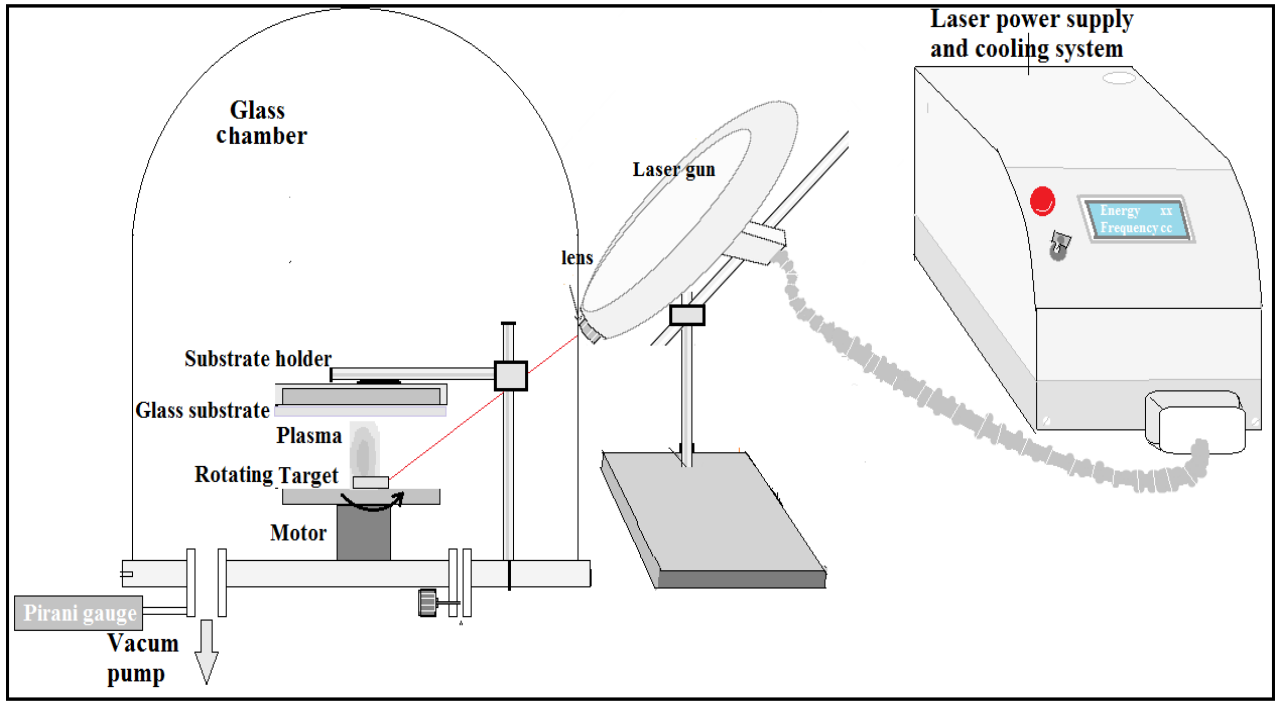

Figure 1. Schematic for pulse laser deposition experimental set up

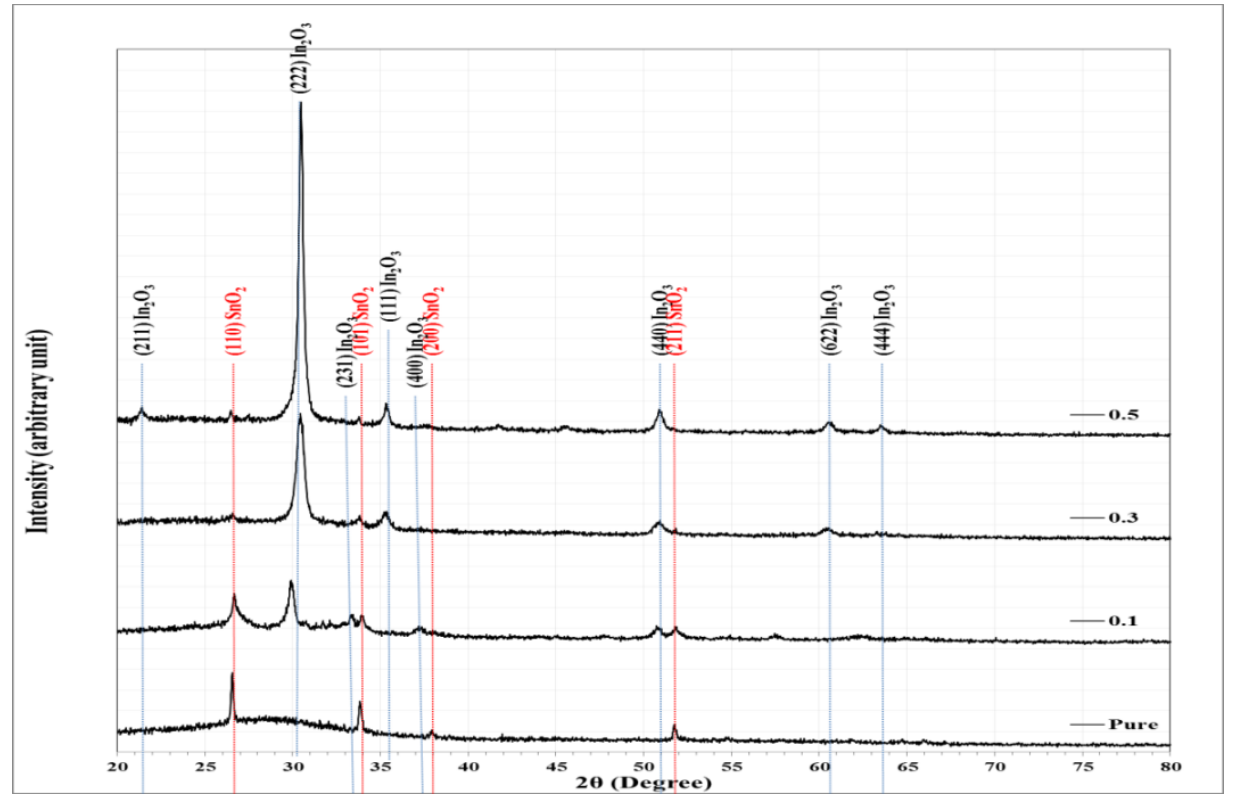

Figure 2. XRD patterns for samples produced by $800 \mathrm{~mJ}$ laser using different $\operatorname{In}_{2} \mathrm{O}_{3}: \mathrm{SnO}_{2}$ ratio 
Table 1. comparison between experimental and standard XRD peak and calculated crystalline size

\begin{tabular}{|c|c|c|c|c|c|c|c|c|}
\hline Ratio & $2 \theta$ (Deg.) & FWHM (Deg.) & dhkl Exp.(Å) & G.S (nm) & hkl & dhkl Std.(Å) & Phase & Card No. \\
\hline & 26.5201 & 0.2150 & 3.3583 & 38.0 & (110) & 3.3498 & $\mathrm{SnO}_{2}$ & 96-210-4744 \\
\hline \multirow[t]{6}{*}{ Pure } & 33.8462 & 0.2170 & 2.6463 & 38.3 & (101) & 2.6439 & $\mathrm{SnO}_{2}$ & $96-210-4744$ \\
\hline & 37.9487 & 0.4395 & 2.3691 & 19.1 & $(200)$ & 2.3686 & $\mathrm{SnO}_{2}$ & $96-210-4744$ \\
\hline & 51.7216 & 0.2930 & 1.7660 & 30.1 & (211) & 1.7642 & $\mathrm{SnO}_{2}$ & 96-210-4744 \\
\hline & 26.6667 & 0.6593 & 3.3402 & 12.4 & (110) & 3.3498 & $\mathrm{SnO}_{2}$ & $96-210-4744$ \\
\hline & 29.8901 & 0.4396 & 2.9869 & 18.7 & (222) & 2.9214 & $\mathrm{In}_{2} \mathrm{O}_{3}$ & 96-101-0589 \\
\hline & 33.4066 & 0.2930 & 2.6801 & 28.3 & (231) & 2.7047 & $\mathrm{In}_{2} \mathrm{O}_{3}$ & 96-101-0589 \\
\hline \multirow[t]{7}{*}{0.1} & 33.9194 & 0.2197 & 2.6407 & 37.8 & (101) & 2.6439 & $\mathrm{SnO}_{2}$ & 96-210-4744 \\
\hline & 37.1429 & 0.5861 & 2.4186 & 14.3 & $(400)$ & 2.5300 & $\mathrm{In}_{2} \mathrm{O}_{3}$ & 96-101-0589 \\
\hline & 38.0220 & 0.4395 & 2.3647 & 19.1 & (200) & 2.3686 & $\mathrm{SnO}_{2}$ & $96-210-4744$ \\
\hline & 50.7692 & 0.5128 & 1.7969 & 17.2 & $(440)$ & 1.7890 & $\mathrm{In}_{2} \mathrm{O}_{3}$ & 96-101-0589 \\
\hline & 51.7949 & 0.5128 & 1.7637 & 17.2 & $(211)$ & 1.7642 & $\mathrm{SnO}_{2}$ & $96-210-4744$ \\
\hline & 26.5043 & 0.5116 & 3.3603 & 16.0 & $(110)$ & 3.3498 & $\mathrm{SnO}_{2}$ & $96-210-4744$ \\
\hline & 30.3776 & 0.4385 & 2.9401 & 18.8 & $(222)$ & 2.9214 & $\mathrm{In}_{2} \mathrm{O}_{3}$ & 96-101-0589 \\
\hline \multirow[t]{7}{*}{0.3} & 33.7393 & 0.4385 & 2.6544 & 18.9 & $(101)$ & 2.6439 & $\mathrm{SnO}_{2}$ & 96-210-4744 \\
\hline & 35.3471 & 0.4385 & 2.5373 & 19.0 & (400) & 2.5300 & $\mathrm{In}_{2} \mathrm{O}_{3}$ & 96-101-0589 \\
\hline & 50.8404 & 0.8039 & 1.7945 & 10.9 & $(440)$ & 1.7890 & $\mathrm{In}_{2} \mathrm{O}_{3}$ & 96-101-0589 \\
\hline & 60.4872 & 0.6577 & 1.5294 & 14.0 & (622) & 1.5256 & $\mathrm{In}_{2} \mathrm{O}_{3}$ & 96-101-0589 \\
\hline & 21.4706 & 0.4412 & 4.1354 & 18.3 & (211) & 4.1315 & $\mathrm{In}_{2} \mathrm{O}_{3}$ & 96-101-0589 \\
\hline & 30.5147 & 0.2206 & 2.9272 & 37.3 & (222) & 2.9214 & $\mathrm{In}_{2} \mathrm{O}_{3}$ & 96-101-0589 \\
\hline & 35.3676 & 0.3676 & 2.5359 & 22.7 & $(400)$ & 2.5300 & $\mathrm{In}_{2} \mathrm{O}_{3}$ & 96-101-0589 \\
\hline \multirow[t]{5}{*}{0.5} & 41.6912 & 0.3677 & 2.1647 & 23.1 & (323) & 2.1576 & $\mathrm{In}_{2} \mathrm{O}_{3}$ & 96-101-0590 \\
\hline & 45.5882 & 0.4412 & 1.9883 & 19.5 & $(341)$ & 1.9847 & $\mathrm{In}_{2} \mathrm{O}_{3}$ & 96-101-0589 \\
\hline & 50.8824 & 0.5147 & 1.7931 & 17.1 & $(440)$ & 1.7890 & $\mathrm{In}_{2} \mathrm{O}_{3}$ & 96-101-0589 \\
\hline & 60.5147 & 0.5148 & 1.5287 & 17.9 & $(622)$ & 1.5256 & $\mathrm{In}_{2} \mathrm{O}_{3}$ & 96-101-0589 \\
\hline & 63.5294 & 0.5147 & 1.4632 & 18.2 & (444) & 1.4607 & $\mathrm{In}_{2} \mathrm{O}_{3}$ & 96-101-0590 \\
\hline
\end{tabular}

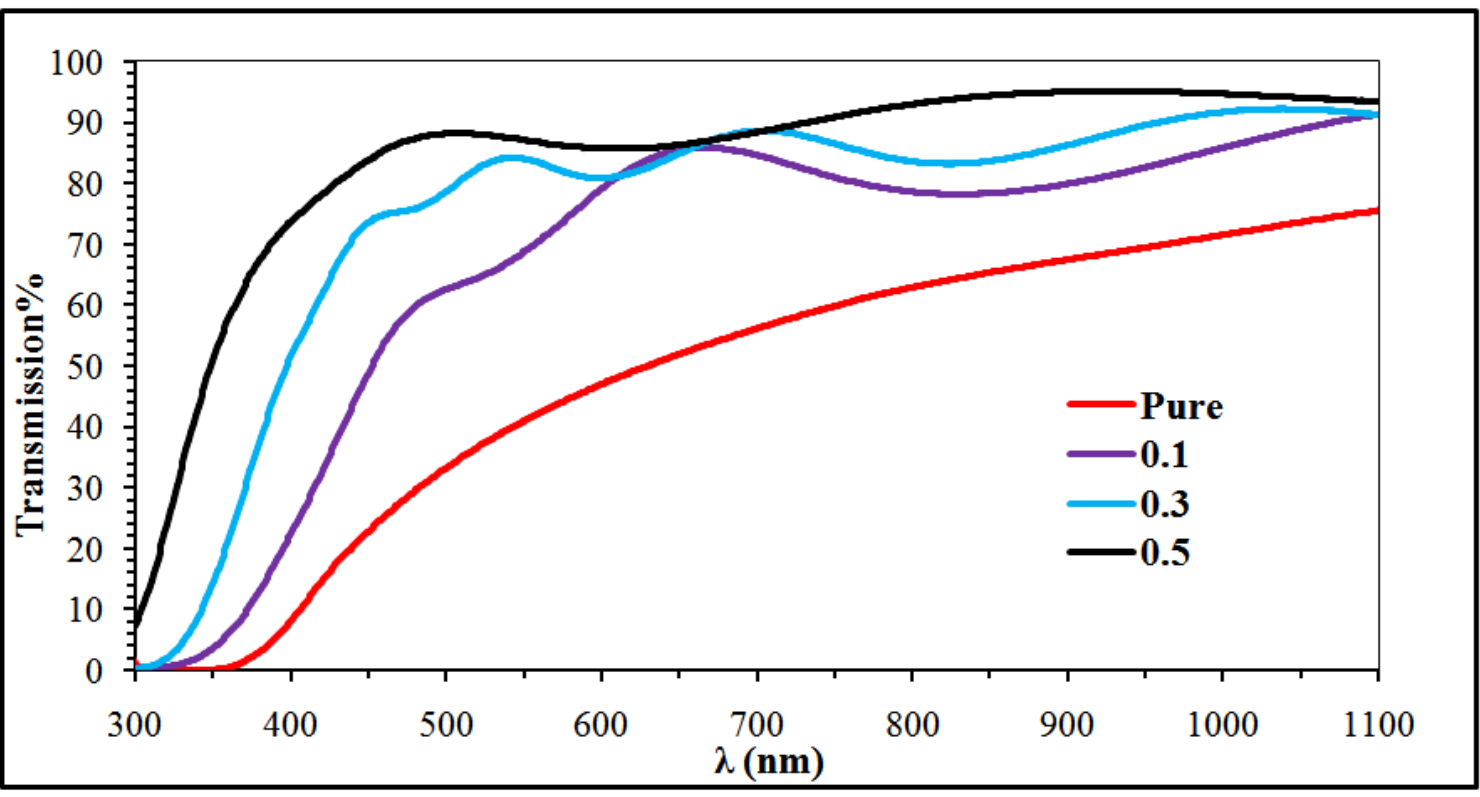

Figure 3. Transmission spectra for $\mathrm{In}_{2} \mathrm{O}_{3}: \mathrm{SnO}_{2}$ with different ratio

Figure 3 shows the transmission spectra for $\operatorname{In}_{2} \mathrm{O}_{3}: \mathrm{SnO}_{2}$ with different ratio. The transmission increase at all range with increasing $\mathrm{In}_{2} \mathrm{O}_{3}$ ratio reaching about $88 \%$ in visible range, as a result of increasing optical energy gap.

The optical energy gap values $\left(\mathrm{E}_{\mathrm{g}}{ }^{\text {opt }}\right)$ for $\mathrm{In}_{2} \mathrm{O}_{3}: \mathrm{SnO}_{2}$ composite films, deposited on glass substrate, annealed at
$773 \mathrm{~K}$ have been determined by using Tauc equation by plotting $(\alpha h v)^{2}$ versus photon energy. The optical energy gap $\left(\mathrm{E}_{\mathrm{g}}{ }^{\mathrm{opt}}\right)$ determined by the extrapolation of the portion at $(\alpha h v)^{2}=0$ as shown in Figure 4. From this figure seems that the energy gap increase from (3.35 to 3.85) eV with increasing $\mathrm{In}_{2} \mathrm{O}_{3}$ ratio from 0 to 0.5 . 


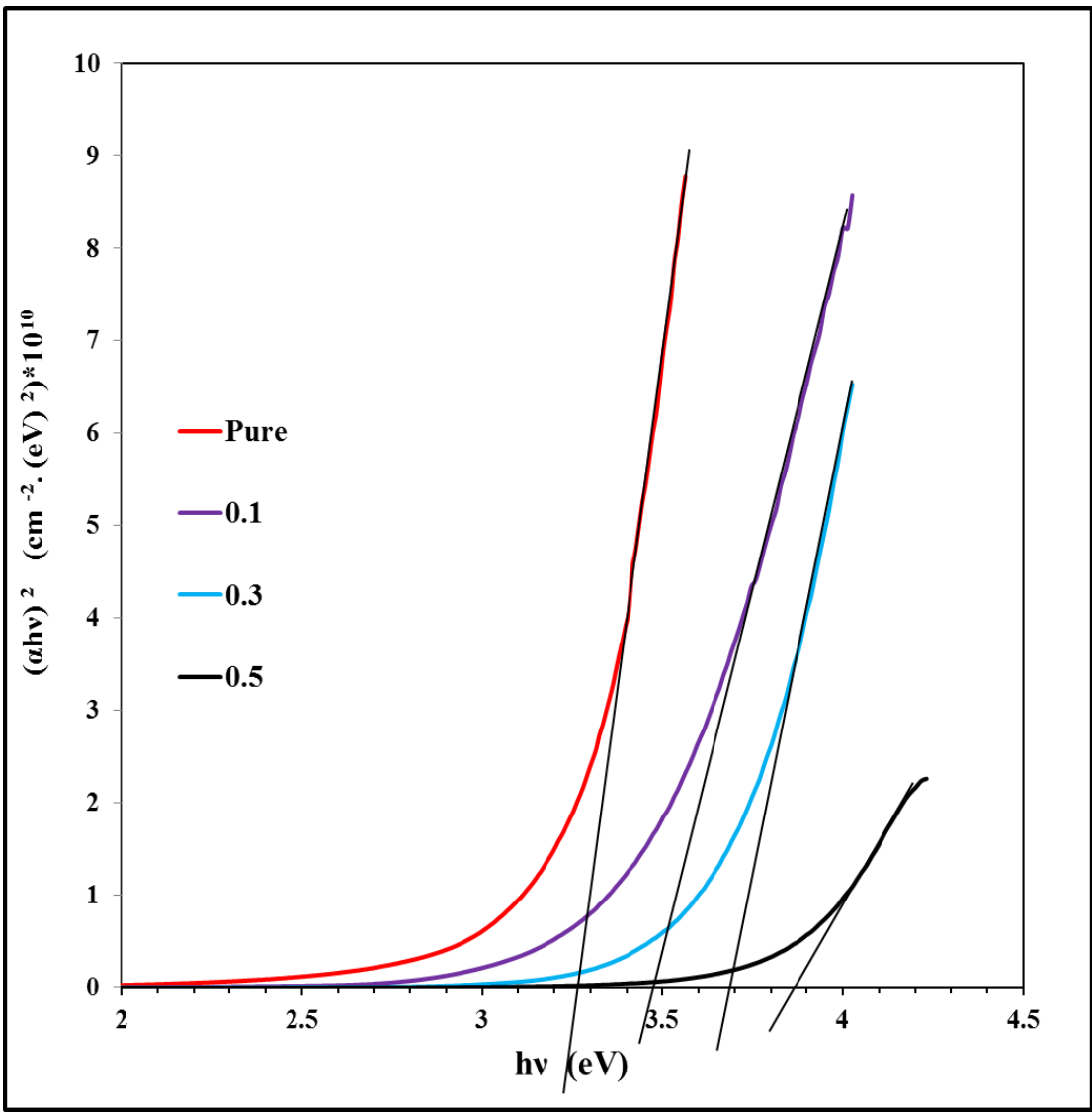

Figure 4. Variation of $(\alpha h v)^{2}$ versus photon energy for $\mathrm{In}_{2} \mathrm{O}_{3}: \mathrm{SnO}_{2}$ thin films with different ratio

The variation of logarithm of DC conductivity with reciprocal temperature for pure $\mathrm{SnO}_{2}$ films and its composite with $\mathrm{In}_{2} \mathrm{O}_{3}$ at different ratio $(0.1,0.3$ and 0.5$)$ annealed at $773 \mathrm{~K}$ were carried out in the temperature range $(303-473) \mathrm{K}$ as shown in Figure 5.

This figure shows that all films have two activation energies and these activation energies decrease with increasing of $\operatorname{In}_{2} \mathrm{O}_{3}$ content. All activation energies and their ranges values have been listed in Table 2. Also it can be seen that the conductivity increase from 0.9046 to $14.8478 \Omega^{-1} . \mathrm{cm}^{-1}$ with increasing ratio from o to 0.3 then decrease to 12.0992 at 0.5 . The DC conductivity increase with increasing $\mathrm{In}_{2} \mathrm{O}_{3}: \mathrm{SnO}_{2}$ ratio due to that (In) ion will act as the donor impurities may occupy shallow donor levels in the film, resulting in the reduction of conduction activation energy [11].

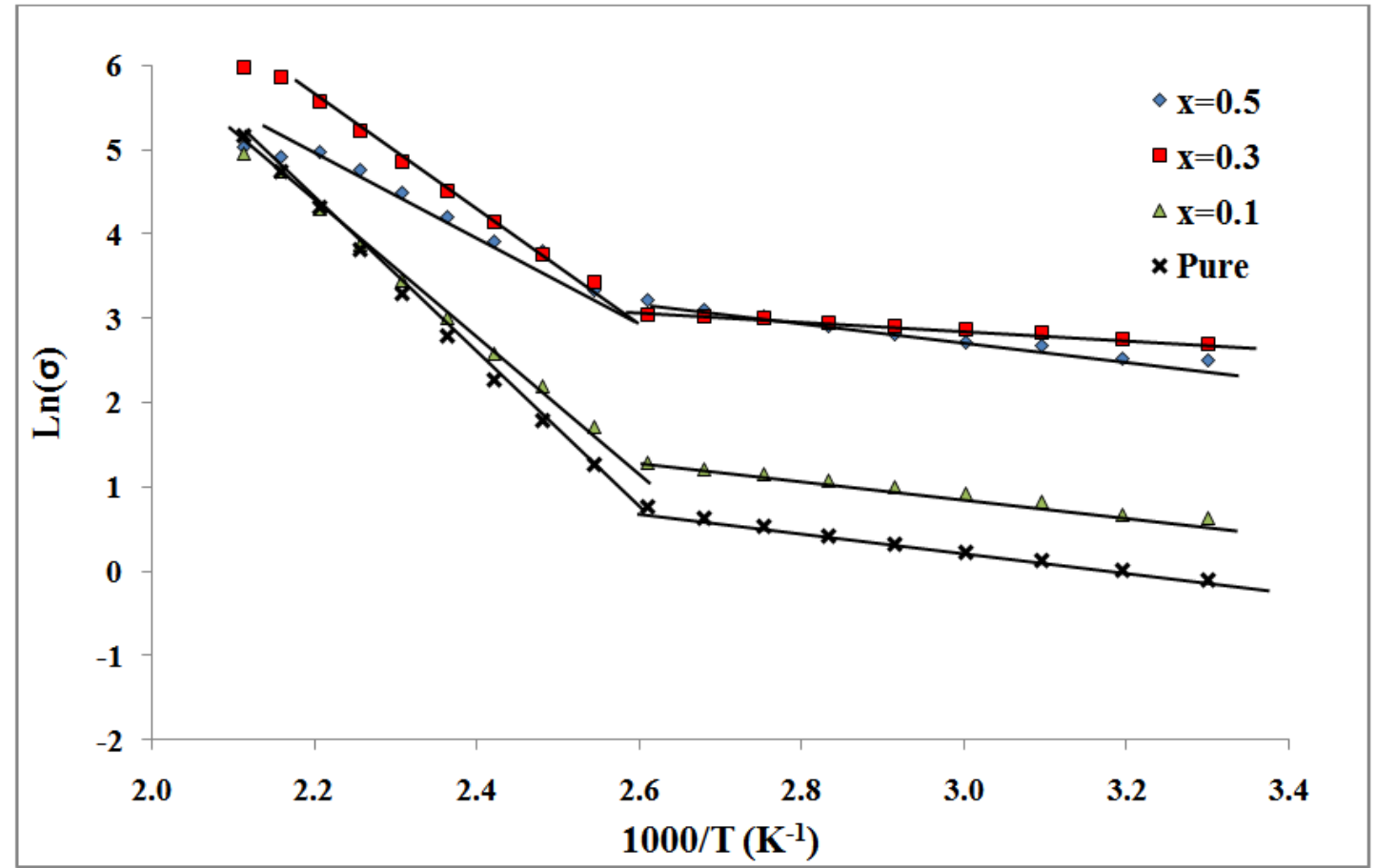

Figure 5. Variation of $\mathrm{Ln}(\sigma)$ with reciprocal temperature for $\operatorname{In}_{2} \mathrm{O}_{3}: \mathrm{SnO}_{2}$ composite thin films with different ratio 
Table 2. DC activation energies, their ranges and conductivity for $\mathrm{In}_{2} \mathrm{O}_{3}: \mathrm{SnO}_{2}$ composite with different ratio

\begin{tabular}{|c|c|c|c|c|c|}
\hline In203:SnO2 & Ea1 $(\mathbf{e V})$ & Range $(\mathbf{K})$ & Ea2 $(\mathbf{e V})$ & Range $(\mathbf{K})$ & $\boldsymbol{\sigma R T}(\mathbf{\Omega}-1 . \mathbf{c m}-1)$ \\
\hline $\mathbf{0 . 0}$ & 0.129 & $303-393$ & 0.792 & $393-473$ & 0.9046 \\
\hline $\mathbf{0 . 1}$ & 0.103 & $303-393$ & 0.667 & $393-473$ & 1.8669 \\
\hline $\mathbf{0 . 3}$ & 0.061 & $303-393$ & 0.537 & $393-473$ & 14.8478 \\
\hline $\mathbf{0 . 5}$ & 0.097 & $303-393$ & 0.346 & $393-473$ & 12.0992 \\
\hline
\end{tabular}

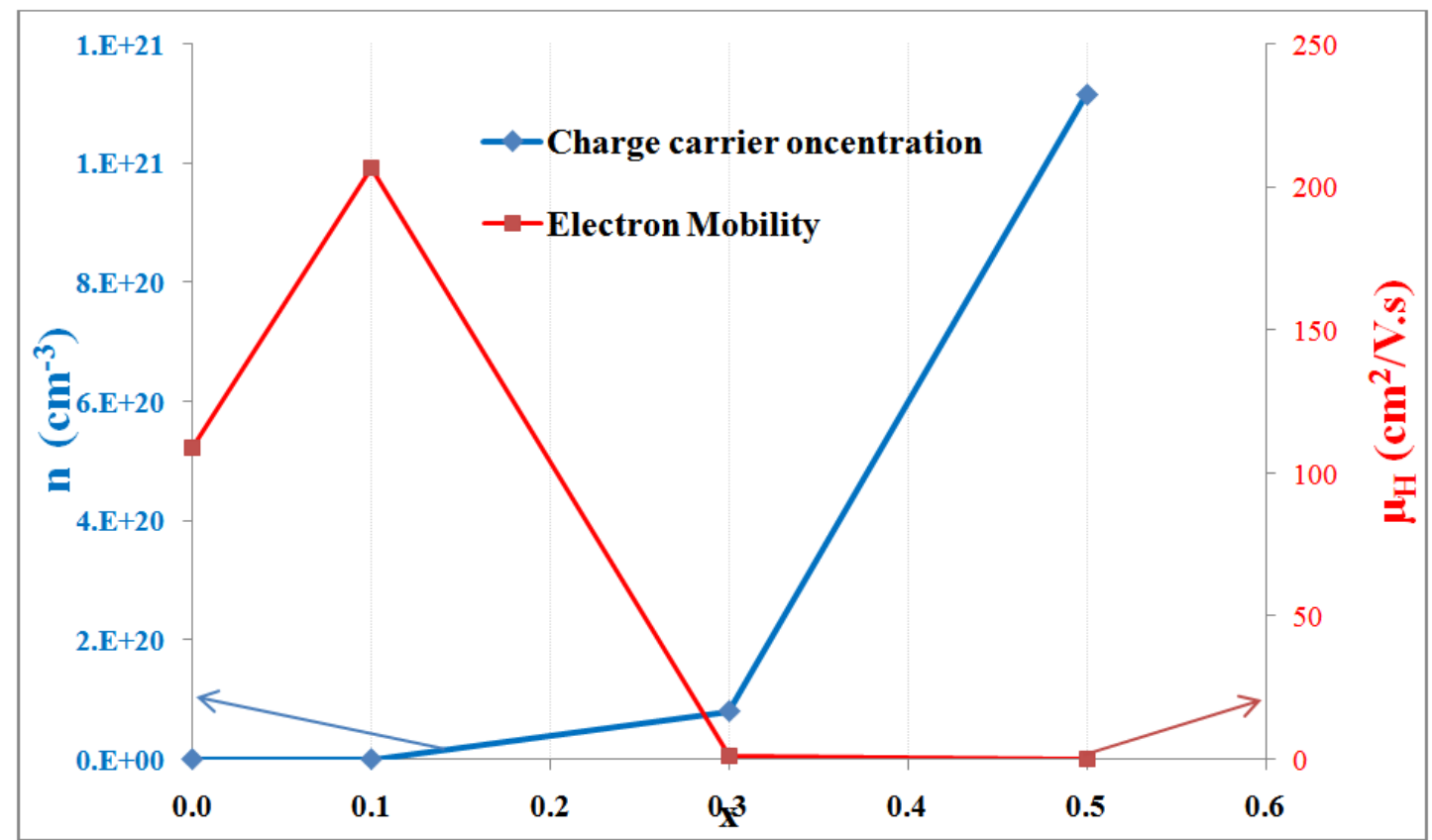

Figure 6. Variation of carrier concentration (n) and mobility $(\mu)$ with dopant ratio

The results obtained from Hall effect show that all films were (n-type). By using of Hall coefficient and films conductivity the charge carrier $\left(\mathrm{n}_{\mathrm{H}}\right)$ and mobility $\left(\mu_{\mathrm{H}}\right)$ have been calculated. The variation of $n_{H}$ and $\mu_{\mathrm{H}}$ with $\operatorname{In}_{2} \mathrm{O}_{3}$ : $\mathrm{SnO}_{2}$ ratio (x) are shown in Figure 6. It is seen that (n) increases with increasing of $\mathrm{In}_{2} \mathrm{O}_{3}$ content to 0.5. Such behavior is expected as a result of the substitution doping of In ${ }^{3+}$ creating one extra free carrier in the process. As the doping level is increased, more dopant atoms occupy lattice sites of $\mathrm{Sn}$ atoms resulting in more charge carriers. while the mobility $\mu_{\mathrm{H}}$ increase at 0.1 ratio then decrease with more $\mathrm{In}_{2} \mathrm{O}_{3}$ content.

\section{Conclusions}

Transparent, electrically conductive films were obtained with good specifications, with a maximum transmission value of $88 \%$ at the visible spectrum. The best samples with $\mathrm{In}_{2} \mathrm{O}_{3}: \mathrm{SnO}_{2}$ ratio equal 0.3 , with an electric conductivity of $14.84 \Omega^{-1} \cdot \mathrm{cm}^{-1}$ and with optical transmission up to $80 \%$, while samples with lower or higher ratio in both measurements have lacking in specification.

\section{References}

[1] H. M. Zeyada, M. M. El-Nahass, I. K. El-Zawawi, and E. M.
El-Menyawy, "Characterization of 2-(2,3-dihydro-1,5- dimethyl3-oxo-2-phenyl-1H-pyrazol-4-ylimino)-2-(4-nitrophenyl) acetonitrile and $\mathrm{ZnO}$ nano-crystallite structure thin films for application in solar cells," The European Physical Journal, vol. 49, p. 10301, (2010).

[2] H. Kim, A. Piqu'e, J. S. Horwitz et al., "Indium tin oxide thin films for organic light-emitting devices," Applied Physics Letters, vol. 74, no. 23, pp. 3444-3446, 1999.

[3] D.G. Parker and P. G. Say, "Indium tin oxide/GaAs photodiodes for millimetric-wave applications," Electronics Letters, vol. 22, no. 23, pp. 1266-1267, (1986).

[4] Y. Huang, Z. Ji and C. Chen, "Preparation and characterization of p-type transparent conducting tingallium oxide films", Applied Surface Science, 253, 4819-4822, (2007).

[5] J. Li, H.Y. Yu, Y. Li, F. Wang, M. Yang, and S. M. Wong, "Low aspect-ratio hemispherical nanopit surface texturing for enhancing light absorption in crystalline $\mathrm{Si}$ thin film-based solar cells", Applied Physics Letters, 98, 021905-021908, (2011).

[6] M. Stella, "Study of Organic Semiconductors for Device Applications," University of Barcelona, 2009.

[7] I. Elfallal, R. D. Rilkington, A. E. Hill. "Formation of a statistical thermodynamic model for the electron concentration in heavily doped metal oxide semiconductors applied to the tindoped indium oxide system", Thin solid films v223, n2, p303-310, Feb. 1993.

[8] H. Hosono, D.C. Paine, Handbook of Transparent Conductors, Springer, New York Heidelberg Dordrecht London, (2010).

[9] W. H. Bragg and W. L. Bragg, X Rays and Crystal Structure. London: G. Bell and Sons, LTD., 1918.

[10] P. Yang, The Chemistry of Nano Structured Materials. Printed in Singapore: World Scientific Publishing Co. Pte. Ltd., p. 362, 2003.

[11] Hestrezeski, D. Thin solid films, Vol. 182, p 1, (1989). 